\title{
Sisi Masalah Kemiskinan dari Sustainable Development Goals melalui Perspektif Ekologi Manusia
}

\author{
Dwiki Faiz Sarvianto ${ }^{1 *}$ \\ ${ }^{1}$ Program Studi Sosiologi Pedesaan FEMA IPB University, Gedung FEMA W1-L2, Kampus IPB \\ Dramaga, Jl. Kamper, Kabupaten Bogor 16680.
}

\section{Kata Kunci: \\ Ekologi manusia, kemiskinan, \\ Sustainable \\ Development Goals \\ (SDGs)}

\begin{abstract}
Abstrak
Secara global, hingga kini upaya untuk mengatasi permasalahan sosialekonomi dengan lingkungan selalu dikaitkan melalui Sustainable Development Goals (SDGs). Namun, di dalamnya sendiri ada masalah kemiskinan sebagai hal utama yang harus dianalisis untuk perencanaan pembangunan ke depannya secara holistik. Kajian ini dengan menggunakan alat analisis three divides, iceberg model, dan systems theory melalui pendekatan kualitatif harus bisa mendeskripsikan fenomena kemiskinan dalam SDGs ini. Hasilnya; ketiga alat analisis tersebut memiliki poin utama masing-masing yang menjelaskan fenomena kemiskinan dalam SDGs sesuai porsinya masing-masing.
\end{abstract}

Keywords:

Human ecology, poverty, Sustainable Development Goals (SDGs)

\begin{abstract}
Globally, efforts to address socio-economic and environmental problems have always been linked through Sustainable Development Goals (SDGs). However, within itself there is the problem of poverty as the main thing that must be analyzed for future development planning holistically. This study using three divides analysis tools, the Iceberg model, and systems theory through a qualitative approach must be able to describe the phenomenon of poverty in these SDGs. The result; the three analysis tools have their main points that explain the phenomenon of poverty in the SDGs according to their respective portions.
\end{abstract}

\section{PENDAHULUAN}

Adanya pertumbuhan penduduk dunia semakin lama semakin banyak dapat menyebabkan permasalahan yang serius untuk keberlanjutan hidup manusia di dunia. Kini, jumlah populasi dunia sudah mencapai \pm 7.7 miliar jiwa dan terus silih berganti (ke jumlah yang lebih banyak) seiring adanya kelahiran dan kematian. Jumlah tersebut menimbulkan dasar pemikiran bahwa bertambahnya penduduk akan memengaruhi tekanan pada keberlanjutan lingkungan nantinya. Hal ini setara dengan pernyataan Hunter (2000:1) bahwa ukuran penduduk secara inheren (berhubungan erat) dengan lingkungan sebagai kebutuhan sumber daya manusia.

Penggunaan lingkungan sebagai kebutuhan tak serta merta dilakukan secara adil pada konteks tatanan aras global dengan adanya pertambahan penduduk. Dominansi pihak-pihak penguasa ataupun perusahaan

\footnotetext{
*Penulis koresponden: faizdwiki@apps.ipb.ac.id
} 
membentuk sebuah ketimpangan pula dalam kesejahteraan dan penggunaan sumber daya alam pada masyarakat miskin atau belum sejahtera. Setara dengan pernyataan tersebut, Wahyuni dan Rusli (2007:358) menjelaskan bahwa ada keterkaitan adanya pertambahan penduduk dengan dominansi pihak yang menggunakan lingkungan secara berlebih mampu menyebabkan kesenjangan pendapatan yang diperoleh masyarakat. Hal ini dapat diilustrasikan sebagai pertambahan penduduk yang semakin banyak namun ruang untuk penghidupan semakin kecil, atau bahkan bila ada pasti hanya berupah kecil.

Tak hanya variabel penggunaan lingkungan yang utama. Wahyuni dan Rusli (2007:356) berpendapat bahwa dengan menggunakan pendekatan sistem, dapat dikatakan sistem penduduk bersama dengan sistem lain pasti saling berhubungan berpengaruh dan menentukan tingkat kesejahteraan penduduk yang dicapai. Singkatnya konteks tersebut menjelaskan bahwa terdapat hubungan kausalitas yang bersifat domino dari sistem kependudukan atau lingkungan pada sistem lain.

Dewasa kini, ruang untuk mencari pendapatan semakin kecil dengan adanya permasalahan lingkungan-penduduk sehingga menimbulkan kemiskinan. Pendapatan yang diperoleh pun mampu menyebabkan pula pola kegiatan terkait konsumsi dan pembuangan limbah sumber daya yang digunakan. Pada masyarakat dengan pendapatan rendah akan menekan lingkungan sebagai tempat pembuangan limbah sehingga menyebabkan kekumuhan, sedangkan masyarakat pendapatan tinggi mampu mengatasi hal itu namun konsumsi energinya dilakukan secara berlebihan karena kemampuannya (Hunter 2000:33). Konteks kesetaraan dalam pendapatan dan kesejahteraan sebenarnya harus terbangun untuk menjadi fokus dalam mengatasi hal tersebut. Tujuan terciptanya kesejahteraan, salah satunya dari segi pendapatan adalah agar terwujudnya paradigma untuk menjaga lingkungan bersamaan dengan pemenuhan kebutuhan masyarakat yang berkelanjutan.

Salah satu upaya masyarakat dunia melalui lembaganya yakni Perserikatan Bangsa-Bangsa (United Nations) untuk mengentaskan permasalahan yang ada melalui program Sustainable Development Goals (SDGs). SDGs dilakukan sebagai program kerja yang dimulai tahun 2015 hingga diproyeksikan tujuh belas tujuannya tercapai pada tahun 2030 di masa yang akan datang. Ketujuhbelas tujuan tersebut dapat dikatakan sebagai pengentasan masalah yang menyelimuti penduduk di seluruh negara, baik negara berkembang ataupun negara miskin, intinya keseluruhan tersebut bersifat holistik dan seperti terikat satu sama lain. Selain itu, konteks permasalahannya pun berbagai dan lintas bidang ada sebagai tujuan pembangunan dunia yang berkelanjutan. Singkatnya, menurut United Nations (2019) pada websitenya, SDGs adalah:

"...At its heart are the 17 Sustainable Development Goals (SDGs), which are an urgent call for action by all countriesdeveloped and developing-in a global partnership. They recognize that ending poverty and other deprivations must go handin-hand with strategies that improve health and education, reduce inequality, and spur economic growth-all while tackling climate change and working to preserve our oceans and forests..."

Bila ditinjau dari tujuan yang diharapkan adanya SDGs seperti yang sudah dibahas, pasti terdapat masalah yang memang menjadi fokus utama, seperti kemiskinan. Kemiskinan diasumsikan menjadi tidak ada lagi dengan adanya SDGs yang mampu mengakhirinya melalui segala pembangunan, hal tersebut terlihat dalam kalimat "that ending poverty". Masalah kemiskinan dipandang sebagai masalah yang cukup sulit dipecahkan dalam masyarakat, terbukti juga bahwa hal tersebut dicantumkan oleh United Nations pada nomor satu; terlepas dari indikator apapun untuk mengurutkan tujuh belas program tersebut.

Bertemakan keberlanjutan, SDGs mencoba menghubungkan pembangunan yang adil dan tidak merugikan siapapun, baik lingkungan maupun penduduk. Hubungan lingkungan dengan penduduk pun menurut Marten (2001:1) dapat dipelajari sebagai sebuah ilmu yang disebut ekologi. Ekologi di dalamnya mengandung semua organisme yang terdapat pada sebuah lingkungan, baik manusia, tumbuhan, hewan, maupun organisme abiotik yang menurutnya disebut sebagai ekosistem. Ekosistem di dunia ini tak berdiri sendiri dan mengatur sistemnya secara mandiri, di samping ekosistem, terdapat sistem sosial 
yang menjadi penyeimbang/sandingan dari ekosistem tersebut. Sistem sosial tergabung dalam sebuah konsep yang di dalamnya terdapat variabel hasil karya/kegiatan manusia sebagai makhluk hidup, seperti teknologi, populasi, nilai, organisasi sosial, dan pengetahuan yang mampu memengaruhi ekosistem sebagai sebuah energi, material, dan informasi (Marten 2001:3). Hal tersebut yang kemudian lebih lanjut disebut oleh dirinya sebagai ekologi manusia. Masalah pembangunan dari latar belakang munculnya program SDGs bila ditelaah secara rinci mencakup keterkaitan antara sistem sosial dengan ekosistem yang ada (ekologi manusia), utamanya dari segi kemiskinan yang berakibat fatal pada kerusakan lingkungan. Oleh karena itu, cukup penting untuk menganalisis lebih jauh keterkaitan yang terjadi dalam masalah SDGs ini, terutama soal kemiskinan di dalam program pembangunan keberlanjutan SDGs itu sendiri.

\section{METODE PENELITIAN}

Kajian ini mengambil masalah-masalah yang ada pada SDGs untuk dikembangkan dan dianalisis. Adapun yang menjadi persoalan utama di dalamnya yakni mengenai kemiskinan. Hal tersebut dikarenakan banyaknya penekanan yang terjadi pada lingkungan beranjak dari kemiskinan tersebut. Selain itu, diakui juga bahwa kemiskinan ini juga menjadi persoalan nomor satu dalam SDGs yang dapat diasumsikan menjadi akar permasalahan manusia-lingkungan.

Kajian ini menggunakan pendekatan kualitatif di dalamnya dengan metode studi pustaka untuk disintesakan menjadi temuan baru dalam konteks masalah SDGs ini. Permasalahan dari SDGs sendiri dalam kajian ini akan dianalisis menggunakan tiga alat analisis: three divides, iceberg model, dan systems theory. Adapun data-data maupun penelitian empiris lainnya bersumber sebagai data sekunder yang didapat dari jurnal dan buku.

\section{HASIL DAN PEMBAHASAN}

\subsection{Masalah pada SDGs melalui Analisis Three Divides}

Sebelum dilakukan analisis pada Sustainable Development Goals (SDGs), lebih baiknya dijelaskan terlebih dahulu mengenai tools analisis dari tiga jurang ketimpangan itu sendiri. Scharmer Otto dan Kaufer Katrin (2013) membagi atas tiga ketimpangan yang terjadi: (1) Ketimpangan ekologi (self $\neq$ nature); (2) Ketimpangan sosial (self $\neq$ other); dan (3) Ketimpangan spiritual (self $\neq$ self). Masing-masing ketimpangan memiliki kasus dan karakteristik yang berbeda satu sama lain. Pertama, ketimpangan ekologi (self $\neq$ earth) menurutnya merupakan fenomena yang terjadi bila manusia terus melakukan degradasi pada lingkungan dengan skala yang masif. Selain itu, kegunaan dan daya lingkungan tidak dapat lagi dijadikan sumber daya dukungan untuk generasi berikutnya (masa depan). Pangan juga tak dapat dihasilkan untuk terus memenuhi kebutuhan masyarakat manakala ketimpangan ini terjadi. Kepedulian akan lingkungan menjadi berkurang apalagi untuk melestarikannya dan menyeimbangkan kegiatannya pada lingkungan yang terusmenerus ditekan. Kasus-kasus yang dijelaskan oleh Scharmer, intinya lebih cenderung kepada krisis yang bersifat rusaknya lingkungan, seperti banjir, kebakaran hutan, dan pencemaran lingkungan (udara, air, dan tanah).

Kedua, berbeda dengan ketimpangan sosial, menurut Scharmer dan Kaufer (2013) terjadi ketika di antara manusia terjadi perbedaan akses dan hasil yang didapatkan untuk memenuhi kebutuhan sehari-harinya. Akses dan hasil ini diasumsikan sebagai ekonomi yang harus didapatkan oleh manusia sebagaimanapun. Dengan begitu, tak heran bila sosial-ekonomi tak dipisahkan oleh Scharmer. Lebih lanjut, dirinya menjelaskan, ketimpangan ini terjadi saat antar individu mementingkan keuntungannya sendiri, namun tidak berbagi kepada sesamanya. Contoh kasus yang Scharmer berikan yakni adanya ketimpangan di dunia bahwa satu persen individu yang memiliki kekayaan terbesar mampu menguasai sembilan puluh persen akses dan sumber daya di dunia ini.

Pada konteks ketimpangan spiritual, manusia diasumsikan sebagai makhluk yang kehilangan sifat manusiawinya. Kesadaran akan dirinya untuk bertindak positif tidak timbul dalam ketimpangan spiritual. Menurut Scharmer, jurang ini membuat banyak manusia kehilangan arah dan mengalami depresi akibat lingkungan luar maupun lemahnya dukungan dari dalam diri. Sebagai individu, dirinya kurang mengetahui jati diri dan hakikinya bila manusia harus tidak individualis, ber-ego 
rendah, dan tidak membuat kerusakan pada apapun.

Setelah dijabarkan, masalah dari SDGs dapat diidentifikasikan masuk klasifikasi jurang ketimpangan berbentuk apa kasusnya. Hal ini seperti yang tertera dalam gambar berikut.



Gambar 1. Masalah dalam SDGs terbagi atas ketimpangan (Scharmer dan Kaufer 2013)

Jurang ketimpangan ekologi yang selama ini terjadi tidak bisa dipisahkan antara manusia dengan lingkungan. Permasalahan mengenai lingkungan kini begitu besar karena adanya pencemaran dimanapun. Meskipun masih ada daerah yang belum terkena pencemaran, namun tak dipungkiri lagi bila nantinya akan terkena pencemaran akibat aktifitas manusia. Bila dikaitkan dan dianalisis pada konteks masalah yang ada dalam Sustainable Development Goals (SDGs), jurang ketimpangan ekologi masuk pada masalah tujuan: $11,12,13,14,15$. Hal tersebut dikarenakan permasalahan yang menjadi latar belakang munculnya tujuan-tujuan itu sangat berkaitan erat dengan lingkungan dan ekosistem yang ada (ekologi). Sesuai dengan pernyataan Scharmer dan Kaufer (2013) bahwa ketimpangan ekologi (self $\neq$ earth) merupakan fenomena yang terjadi bila manusia terus melakukan degradasi pada lingkungan dengan skala yang masif sehingga menimbulkan kerusakan. Kepedulian akan lingkungan menjadi berkurang apalagi untuk melestarikannya dan menyeimbangkan kegiatannya pada lingkungan yang terusmenerus ditekan.

Konteks yang terjadi pada masalah pembangunan tujuan sebelas (11) yakni ketidakberlanjutannya pembangunan masyarakat dengan lingkungan sekitarnya sebagai tempat tinggal masih terjadi. Berdasarkan tujuan sebelas (11), pembangunan lingkungan yang berkelanjutan dengan manusia sebagai penduduknya mesti diupayakan agar sistemnya seimbang. Rata-rata kasus masalah yang ada, pembangunan lingkungan tak memedulikan manusianya, atau bahkan sebaliknya. Masalah tersebut dapat dicontohkan oleh kasus yang terjadi di Indonesia melalui riset Pratiwi (2008:106). Pratiwi (2008) menyatakan bahwa secara umum dalam beberapa dasawarsa terakhir Indonesia terus melaksanakan pembangunan, namun seiring banyaknya masalah juga, menyebabkan pembangunan seperti sia-sia dan tidak berlanjut. Dirinya menyebutkan bahwa secara umum permasalahan lingkungan hidup di Indonesia terdapat lima pokok hal: pencemaran, pemanfaatan alam secara tidak terkendali, kepadatan penduduk, menurunnya populasi fauna, dan ketidakseimbangan ekosistem-ekosistem. Atas pernyataan Pratiwi (2008) pula bila masalah lingkungan hidup di Indonesia belum selesai untuk mengatasinya. Konsep keberlanjutan yang sebagaimana mesti dapat digunakan secara baik pada masa depan (untuk generasi mendatang) tidak akan pernah terwujud bila masyarakatnya melakukan konsumsi terus-menerus tanpa memerhatikan lingkungan yang ada. Secara garis besar pun, lingkungan tidak dapat mengimbangi pertumbuhan masyarakat yang begitu pesat, baik secara kuantitas maupun kualitas.

Masalah pembangunan yang terjadi pada tujuan dua belas (12) konteksnya tentang produk konsumsi yang digunakan oleh masyarakat. Hal tersebut secara terus-menerus menimbulkan masalah pada lingkungan secara luas, contoh kasusnya seperti di Indonesia. Adanya tujuan tersebut, diharapkan konsumsi yang dilakukan masyarakat mampu menurun dengan penggunaan energi yang begitu efisien dan efektif. Konsumsi yang begitu besar mampu menyebabkan sampah atau buangan energi yang sia-sia. Menurut data Statistik Lingkungan Hidup Indonesia yang dikeluarkan Badan Pusat Statistik (BPS) pada tahun 2018, data tersebut menyebutkan bahwa saat tahun 2016 jumlah timbunan sampah di Indonesia mencapai 65.200.000 ton per tahun dengan penduduk sebanyak 261.115.456 orang. Hal itu mengindikasikan sangat banyak sampah yang dibuang setiap orangnya per tahun. Jumlah tersebut belum lagi dikategorikan ke dalam jenis/bahan sampah yang terbuang ke air (sungai)/laut, seperti bahan plastik. Jenis sampah berbahan plastik yang sulit terurai bila 
dibuang ke sungai/laut akan menyebabkan pencemaran air maupun merusak kehidupan hewan laut, seperti masalah yang ada pada tujuan empat belas (14) yakni rusaknya ekosistem bawah laut. Hal ini pun setara dengan pernyataan dari Uar et al. (2016:89) bila kerusakan terumbu karang pun dapat disebabkan oleh aktifitas konsumsi manusia di bidang perikanan. Selain terumbu karang, makhluk hidup lainnya pun dapat punah akibat aktifitas sampah yang ada di laut. Atas kedua kasus tersebut, dari permasalahan tujuan dua belas (12) pun bisa mengaitkan permasalahan lain di tujuan empat belas (14) pada SDGs; hal ini sudah mengindikasikan bila sistem yang positif harus dibangun.

Sedikit berbeda bila membahas iklim dan kehidupan pada lahan terbuka/tertutup, seperti hutan yang ada di tujuan tiga belas (13) dan lima belas (15) pada SDGs. Keterkaitan iklim dengan kerusakan lahan hubungannya sangat erat. Namun, biasanya rata-rata perubahan iklim disebabkan oleh adanya aktifitas kerusakan pada ekosistem lingkungan, seperti hutan. Iklim dalam hal ini bisa dikatakan sebagai variabel yang dipengaruhi secara kuat oleh aktifitas/kondisi lingkungan seperti adanya deforestasi hutan yang diungkapkan oleh Mawalagedara $\mathrm{R}$ dan Oglesby R (2012:3). Pernyataan tersebut bahkan Mawalagedara R dan Oglesby (2012:6) ambil dari kondisi lapang di negara Asia Selatan dan Tenggara, hal ini mengindikasikan bila Indonesia dan negara Asia Selatan serta Tenggara lainnya turut saling berkaitan untuk memengaruhi iklim regional. Dengan SDGs, diharapkan connected bersama negara lain dapat mengatasi permasalahan tersebut. Apalagi mengenai pembakaran hutan, yang efeknya pun bisa ke beberapa negara untuk merasakan dampaknya.

Tak sampai di situ saja, permasalahan yang ada pada tujuan tiga belas (13) dan lima belas (15) pun saling berhubungan, apalagi dengan maraknya kasus penebangan pohon, serta ekspansi perusahaan untuk mengeksploitasi sumber daya alam yang terusmenerus. Konteks iklim dan kerusakan hutan menjadi catatan tersendiri dengan adanya SDGs, karena kedua permasalahan tersebut merupakan masalah yang besar dan lebih sulit daripada merubah pola konsumsi atau pembangunan masyarakat yang ada pada bahasan sebelumnya. Selain masalah-masalah jurang ketimpangan ekologis, terdapat pula masalah hubungan antar manusia sebagai subjek kehidupan di dunia ini yang bisa disebut sebagai jurang ketimpangan sosial ekonomi.

Jurang ketimpangan sosial bisa diambil pengertiannya dari simbol (Self $\neq$ Other) yang dimaksudkan merupakan cerminan putusnya hubungan dengan sesama karena keuntungan semata-mata yang harus diambil. Atas keuntungan tersebut pula, jurang ketimpangan ini tak hanya ketimpangan sosial. Di sisi lain, ketimpangan tersebut bersamaan dengan ketimpangan ekonomi juga karena pendapatan yang dihasilkan berbeda hingga menyebabkan adanya kemiskinan.

Bila dikaitkan dengan Sustainable Development Goals (SDGs), maka permasalahan pembangunan di dalam SDGs ada pada tujuan satu (1) hingga sepuluh (10). Masalah-masalah tersebut secara berurutan berupa: kemiskinan, kelaparan, masyarakat yang rentan sakit (kurang gizi), rendahnya pendidikan, ketimpangan gender, sanitasi/air tercemar, banyak energi boros, pertumbuhan ekonomi tidak merata (termasuk pekerjaan), industri dan pembangunan infrastruktur tidak menganut keberlanjutan, dan ketimpangan akses (peluang) pertumbuhan yang terjadi di banyak negara. Tak terbantahkan bila ketimpangan sosial ekonomi dalam masalah pembangunan SDGs merupakan terbanyak dan saling berkaitan pula. Namun, bila disandingkan dengan indikator Badan Pusat Statistik (BPS) yang dimiliki pemerintah, nampaknya masalah ketimpangan sosial ekonomi yang ada hampir sama dengan permasalahan pada indikator kesejahteraan menurut BPS. Tahun 2018, BPS mengeluarkan indikator kesejahteraan rakyat yang di dalamnya terjadi dalam delapan bidang: kependudukan, kesehatan dan gizi, pendidikan, ketenagakerjaan, taraf dan pola konsumsi, perumahan dan lingkungan, kemiskinan, dan sosial. Dengan arti lain, hal tersebut mengartikan bahwa Indonesia sebagai suatu contoh kasus, masih mengalami hal-hal jurang ketimpangan sosial ekonomi dengan indikator pembangunan BPS dan SDGs yang menunjukkan perbedaan masing-masing bidang memiliki permasalahan tersendiri.

Apabila masalah yang ada pada SDGs dan BPS diasumsikan sebagai suatu hal yang terikat satu sama lain, maka tak bisa disalahkan juga bila SDGs maupun BPS menempatkan kemiskinan menjadi faktor paling penting. Jurang ketimpangan sosial ekonomi yang 
menyebabkan kemiskinan pasti terjadi dikarenakan adanya ketimpangan akses pula dalam hal keuntungan. Benar kata Marx bahwa golongan kaya akan selalu mencari keuntungan terus-menerus tanpa memerhatikan sesamanya yang berada di golongan bawah, dan bila golongan bawah mendobrak untuk "mengambil" kekayaannya, hal tersebut tidak akan bisa (Magnis-Suseno 2016). Demikian pula terjadi gap ketimpangan yang semakin membesar. Adanya SDGs diharapkan setidaknya memperkecil/menekan angka kemiskinan di level global yang kini makin integrated dengan adanya modernisasi dan globalisasi. Atas hal itu, ketika masalah kemiskinan sudah diperbaiki, kesejahteraan yang lain pun dapat terpenuhi.

Namun, masalah kemiskinan yang ada di nomor satu SDGs tentu tak serta merta berevolusi dengan cepat hingga tak menyebabkan masalah lain hingga tujuan nomor sepuluh dalam hal ketimpangan sosial ekonomi. Hal ini menjadi dilema tesendiri bila disetarakan dengan teori Hunter. Masyarakat dengan pendapatan rendah akan menekan lingkungan sebagai tempat pembuangan limbah sehingga menyebabkan kekumuhan, sedangkan masyarakat pendapatan tinggi mampu mengatasi hal itu namun konsumsi energinya dilakukan secara berlebihan karena kemampuannya (Hunter 2000:33). Secara singkat, miskinnya masyarakat mampu membuat permasalahan tujuan lain ikut ada. Hal tersebut seperti kasus kemiskinan yang mampu menyebabkan lingkungan masyarakatnya menjadi tidak sehat sehingga memunculkan penyakit (kelaparan dan kurang gizi) dan masalah lingkungan lainnya (sanitasi); sedangkan masyarakat kaya atau mampu mengonsumsikan energi yang banyak namun tidak memerhatikan pemanasan global dan perubahan iklim. Belum lagi soal akses pendidikan dan pekerjaan, di dalamnya ada ketimpangan soal kemudahan dalam mengakses informasi dan persoalan gender yang seringkali menghalangi akses bagi perempuan. Hal tersebut yang kemudian juga makin memiskinkan kondisi masyarakat dan memperjauh harapannya dari kesejahteraan yang kemudian peran SDGs harus digaungkan. Sebagai agenda kerja hingga 2030, SDGs menjadi agent of change untuk memperbaiki masalah-masalah yang terjadi di level global. Narasi tersebut melihat konteks masalah ekonomi bisa ditimbulkan dengan adanya keterkaitan ekonomi dengan negara maju yang menunjukkan kebergantungan. Ketergantungan tersebut pula yang tidak bisa dilepaskan bagi negara miskin/berkembang karena belum kesiapannya membangun negaranya secara mandiri. Berdasar masalah dan harapan sebelumnya, mau tidak mau, jurang ketimpangan sosial ekonomi bila tidak diatasi melalui SDGs sekalipun, nantinya akan merembet pada hal-hal lain. Hal lain tersebut bisa berupa masalah lingkungan/ekologi lainnya seperti yang sebelumnya dipaparkan maupun landasan spiritual yang juga terdapat ketimpangan di dalamnya, hal tersebut membuat kompleksitas jurang ketimpangan apapun.

Bila diulas dalam jurang ketimpangan ekologi dan sosial ekonomi, narasi keterlibatan manusia menjadi subjek pembangunan atau permasalahan sangat lah penting untuk dimunculkan. Manusia menjadi aktor dari segala perubahan yang ada di dunia. Hal tersebut tak terlepas dari sifat internal dalam dirinya yang membentuk apakah dirinya menjadi manusiawi atau tidak. Kemanusiaan atau sifat manusiawi seseorang merupakan bentuk spiritual yang dimiliki setiap individu untuk menjalani kehidupannya.

Dewasa kini, jurang ketimpangan spiritual turut menjadi masalah global menurut Scharmer. Konteks ketimpangan spiritual menurutnya, manusia diasumsikan sebagai makhluk yang kehilangan sifat manusiawinya. Kesadaran akan dirinya untuk bertindak positif tidak timbul dalam ketimpangan spiritual. Menurut Scharmer dan Kaufer (2013), jurang ini membuat banyak manusia kehilangan arah dan mengalami depresi akibat lingkungan luar maupun lemahnya dukungan dari dalam diri. Sebagai individu, dirinya kurang mengetahui jati diri dan hakikinya bila manusia harus tidak individualis, ber-ego rendah, dan tidak membuat kerusakan pada apapun.

Bila dikaitkan pada Sustainable Development Goals (SDGs), jurang ketimpangan spiritual terjadi dalam masalah tujuan pembangunan ke-16 dan 17. Hal tersebut mengartikan bila masalah pada tujuan enam belas (16), yakni ketidakadilan, konflik, dan KKN (Korupsi, Kolusi, dan Nepotisme) dalam kelembagaan masih terjadi di level global maupun mikro. Keadilan, minimnya konflik, dan tidak adanya kasus KKN menjadi agenda besar SDGs karena masih ditemukan kasus-kasus yang berkaitan dengan jurang 
ketimpangan spiritual, contohnya konflik karena ketidakadilan. Avis WR (2019:2) mengatakan bahwa ketidakadilan dapat menyebabkan konflik hingga kini dan menjadikan sebuah masalah yang kompleks karena banyaknya dampak yang ditimbulkan. Dirinya menyebutkan bahwa terdapat sekitar 2 miliar orang (sekitar sepertiga dari populasi dunia) tinggal di negara yang terkena dampak konflik dan membahayakan. Menambahkan lagi dari pernyataannya bahwa 2 miliar orang tersebut rentan akan mengalami kematian dan kemiskinan terus-menerus; hal ini mengindikasikan bila jurang ketimpangan sosial ekonomi bisa terjadi karena ketimpangan spiritual. Bahkan studi dari Schafer (2018) menyebutkan bahwa setiap tahunnya, konflik yang terdapat pada seluruh dunia merugikan seluruh negara hingga 13,6 triliun dollar. Hal tersebut pula dirinya menyebutkan bahwa agenda 2030 alias SDGs dapat terganggu dengan adanya konflik. Belum lagi persoalan korupsi seperti yang terjadi di Indonesia, Komisi Pemberantasan Korupsi (KPK) memenjarakan berbagai pejabat negara hingga unit terkecil akibat korupsi. Hal tersebut menambah daya usaha SDGs untuk mengentasan kasus melalui tujuan enam belas (16), yakni keadilan dan kedamaian demi terciptanya kedaulatan masyarakat yang bertatanan sejahtera dan bahagia.

Adanya tujuan tertentu, keuntungan, dan hilangnya sifat manusiawi dalam kehidupan, dapat mendorong juga permasalahan ke-17 dalam SDGs terus terjadi, yakni individualistik, egosentrik, dan keserakahan manusia yang kemudian tidak akan menciptakan partnership dalam mencapai tujuan bersama. Padahal bila dilihat secara positif, kemitraan yang dimaksudkan SDGs yakni adanya kolaborasi (jejaring) kelembagaan antar sistem sosial di masyarakat mampu menyejahterakan masyarakat itu sendiri. Kasus yang kini masih ada tentang spiritual dengan sifat negatifnya manusia dinyatakan oleh Sfeir Younis (2004), bahwa di era millenial kini, instrumen politik dan kondisi sosial dunia semakin mengalami kekosongan dalam hal etika dan moral politik untuk menentukan kebijakan setiap negara. Kasus ini menjadi penting juga lantaran nilai spiritual termasuk pada menyikapi diri sebagai makhluk ciptaan Tuhan. Bila ketidakadaan nilai spiritual/moral, maka jauh juga manusia dari Sang Pencipta.

Tiga jurang ketimpangan yang dipaparkan memiliki karakteristik masingmasing pada masalah dalam pembangunan SDGs. Padahal, SDGs tersebut ada untuk terciptanya hal yang adil bagi level dunia. Namun, kontekstual yang terjadi memang sulit direalisasikan hingga kini. Masalah yang terjadi nampaknya harus dilakukan secara bersama melalui agenda yang besar pada SDGs. Agenda konkrit tersebut nantinya dapat untuk meredam jurang ketimpangan agar tak semakin meluas.

Adanya kompleksitas dalam masalah jurang ketimpangan tersebut, meninjaunya pun harus disertai dengan systems thinking dan menggunakan tools yang mampu melihat masalah tersebut secara terstruktur maupun sistematis sebelum bertindak. Oleh karena itu, dibutuhkan pula analisis lain untuk pendekatan masalah pembangunan yang ada pada SDGs di level manapun.

\subsection{Masalah pada SDGs melalui Analisis Iceberg Model}

Menurut Monat J (2015:13), iceberg model salah satu alat analisis yang membantu mengenalkan hubungan antar komponen yang mendalam pada suatu sistem terkait permasalahan seperti kemiskinan. WWF (2019:18) sendiri menyebutkan bahwa iceberg model diadaptasi dari teori yang dikeluarkan oleh Goodman. Konsep iceberg model dari Goodman tersebut berisikan urutan dari yang nampak hingga suatu latar belakang terjadinya masalah seperti kemiskinan melalui event (peristiwa yang nampak), patterns (pola dan tren), structures (sistem terstruktur sebagai penyebab), and mental models (paradigma) pada tabel 1 di bawah.

Tabel 1. Matriks analisis iceberg model

\begin{tabular}{lll}
\hline Aspek & Komponen masalah & Pilihan respon \\
\hline Events & $\begin{array}{l}\text { Fenomena kemiskinan di seluruh } \\
\text { dunia }\end{array}$ & $\begin{array}{l}\text { Melawan adanya ketimpangan } \\
\text { akses dan hasil seperti Marxian } \\
\text { untuk peningkatan pendapatan } \\
\text { masyarakat umum }\end{array}$ \\
& Perkembangan pembangunan & Pembangunan kemajuan ipteks \\
\hline
\end{tabular}




\begin{tabular}{|c|c|c|}
\hline Aspek & Komponen masalah & Pilihan respon \\
\hline & $\begin{array}{l}\text { melalui teknologi atau } \\
\text { industrialisasi tanpa memerhatikan } \\
\text { sumber daya manusia dan alam } \\
\text { yang kompleks di seluruh sumber } \\
\text { daya, sejak dahulu hingga kini } \\
\text { menyebabkan ketimpangan antara } \\
\text { golongan kaya dan miskin. Secara } \\
\text { singkat timbul narasi: "yang miskin } \\
\text { makin miskin, yang kaya makin } \\
\text { kaya". }\end{array}$ & $\begin{array}{l}\text { harus disertai antisipasi resiko yang } \\
\text { ada dengan memerhatikan sistem } \\
\text { sumber daya manusia dan alam } \\
\text { yang terbatas. }\end{array}$ \\
\hline Structures & $\begin{array}{l}\text { Adanya sistem birokrasi (perizinan } \\
\text { apapun dikeluarkan untuk usaha } \\
\text { eksploitasi sumber daya alam) yang } \\
\text { KKN maupun kapitalisme yang } \\
\text { terus-menerus: mencari keuntungan } \\
\text { dengan mengupahkan buruh dengan } \\
\text { murah, ekspansi produknya ke } \\
\text { berbagai wilayah, dan } \\
\text { ketidakpedulian terhadap people } \\
\text { dan planet }\end{array}$ & $\begin{array}{l}\text { Menata ulang sistem birokrasi dan } \\
\text { kapitalis dengan data yang lebih } \\
\text { presisi dengan tujuan agar program } \\
\text { pembangunan dan ketepatan } \\
\text { mengatasi masalah lingkungan } \\
\text { semakin membaik. }\end{array}$ \\
\hline Mental models & $\begin{array}{l}\text { Sistem bertahan dengan adanya } \\
\text { asumsi dan paradigma: "dengan } \\
\text { uang bisa segalanya" }\end{array}$ & $\begin{array}{l}\text { Paradigma "dengan uang bisa } \\
\text { segalanya" seharusnya } \\
\text { dipertanyakan. Bagaimana keadaan } \\
\text { memiliki sedikit uang dimiliki oleh } \\
\text { sebagian banyak orang? Tentu hal } \\
\text { tersebut membuat ketimpangan } \\
\text { begitu jauh gap-nya. Selain itu } \\
\text { melanggengkan segala bentuk } \\
\text { penindasan bagi orang miskin } \\
\text { dengan birokrasi ataupun kapitalis. } \\
\text { Ketimpangan semakin terjadi terus } \\
\text { menerus pada akhirnya. }\end{array}$ \\
\hline
\end{tabular}

Bila ditinjau pada tabel 1, adanya permasalahan kemiskinan yang termasuk jurang ketimpangan sosial ekonomi harus segera ditekan untuk mewujudkan kesejahteraan bagi masyarakat. Hal yang harus dibenahi dari tingkat tapak memang aspek mental models, paradigma yang dibangun harus diuji kembali melalui asumsi: "siapa yang dirugikan bila semua harus dilakukan untuk uang?". Dengan pengujian asumsi tersebut, segalanya akan merubah hingga ke aspek realitas yang ada. Kondisi kemiskinan ini sudah menjadi masalah yang tak tuntas sama sekali hingga sekarang, setidaknya menekan seminimal mungkin kemiskinan itu terjadi.

\subsection{Masalah pada SDGs melalui Analisis Systems Theory}

Perkembangan program kerja Sustainable Development Goals (SDGs) bila dilihat secara teliti tentu memiliki tujuan ideal. Adanya pemekaran dari yang hanya berjumlah delapan tujuan pada MDGs menjadi tujuh belas tujuan pembangunan dalam SDGs, tentu dimaksudkan untuk mengatasi masalah kompleksitas yang terjadi. Kompleksitas dalam hal ini menciptakan sebuah sistem yang saling terikat satu sama lain antar masalah yang terjadi. Adanya sistem pada kompleksitas masalah menuntut solusinya pun harus bersifat sistematis juga, alias melihat secara luas juga pandangan yang dimiliki setiap individu. Mulai dari pikiran, gagasan, dan solusinya semuanya harus bersifat kompleks dan tersistem saling memengaruhi.

Menurut Meadows D dalam bukunya mengenai "Thinking in Systems: From the lead autgor of the international", sistem merupakan:

“...isn't just any old collection of things. A system is an interconnected set of elements that is coherently organized in a way that achieves something. If you look at that definition closely for a minute, you can see that a system must consist of three kinds of things: elements, interconnections, and a function or purpose..." 
Pada pernyataan Meadows tersebut (2008:11), terdapat tiga kata kunci yang menjadi poin untuk dikembangkan sebagai systems theory. Ketiga kata tersebut adalah elemen, keterhubungan satu sama lain, dan tujuan/ fungsi agar mencapai kebutuhan yang diinginkan. Bila dikaitkan dengan realitas yang ada terkait permasalahan kemiskinan di Indonesia dan masalah pembangunan pada SDGs, kemiskinan dapat dikategorikan sebagai masalah yang urgent karena belum bisa diselesaikan hingga kini.

Adanya systems theory dinilai Meadows mampu menembus/memperluas sudut pandang yang ada pada suatu masalah untuk membuat suatu solusi yang memungkinkan dilakukan. Pada analisis menggunakan systems theory terkait permasalahan kemiskinan, penulis mengambil elemen yang urgent di Indonesia, hal ini mengaitkan kemiskinan dengan pendidikan, ketenagakerjaan, dan kesehatan. Ketiga elemen tersebut didasarkan atas keselarasan indikator BPS dengan tujuan pembangunan yang ada pada program kerja SDGs terkait pengentasan masalah kemiskinan di Indonoesia. Selain itu, yang diambil hanya ketiga indikator ini karena mengingat keterbatasan waktu yang digunakan dalam menulis makalah ini. Oleh karena itu, sangat ditekankan bila tidak menutup kemungkinan adanya elemen lain yang terikat/ berhubungan dengan masalah kemiskinan di mahzab tulisan lain.

Elemen pertama, pendidikan begitu penting bila ingin mengentaskan masalah kemiskinan di Indonesia. Dengan adanya pendidikan, informasi dan pengetahuan dapat diperoleh masyarakat sebagaimana bermanfaat untuk menjalani kehidupan sehari-hari nya agar terhindar dari kemiskinan. Akan tetapi, dari segi lama sekolah pun Badan Pusat Statistik (2018) menyebutkan bila rata-rata masyarakat Indonesia hanya bersekolah selama 8 tahun, yang artinya kebanyakan masyarakat di Indonesia hanya mengeyam pendidikan sampai kelas dua (2) SMP. Padahal dengan adanya pendidikan, setidaknya tata cara berperilaku dapat diketahui/dilakukan setiap masyarakat.

Selain pendidikan, ketenagakerjaan menjadi elemen kedua turut menjadi suatu hal yang krusial bila dikaitkan dengan penciptaan lapangan kerja. Adanya lapangan pekerjaan yang disebutkan dalam SDGs dapat meningkatkan pendapatan setiap individu demi terwujudnya kehidupan yang cukup/terhindar dari kemiskinan. Tetapi, cara itu bisa terjadi bila upah yang dibayarkan pun mencukupi kebutuhan sehari-hari. Hal itu bisa dipermasalahkan lantaran ditemukan juga oleh BPS (2019) yang menyebutkan bila di Indonesia ini terdapat 7 dari 17 kategori lapangan pekerjaan dengan rata-rata upah buruh lebih rendah daripada rata-rata upah buruh nasional. Padahal bila dikaitkan dengan teori Marx, upah buruh dalam konteks tersebut bisa menyiptakan ketimpangan kelas terusmenerus dan menyebabkan buruh masuk ke jurang kategori miskin yang dalam.

Terakhir sebagai elemen ketiga yang dipilih, yakni tentang kesehatan, dimana hal ini turut menjadi elemen penting sebagai dampak adanya kemiskinan. Di Indonesia, masalah kesehatan turut menyelimuti orang-orang miskin di berbagai daerah. Data BPS menyebutkan setiap tahunnya dari 2011 hingga 2018, keluhan kesehatan pada masyarakat Indonesia mengalami peningkatan terusmenerus. Walaupun keluhan kesehatan tak semuanya dialami oleh masyarakat miskin, namun, perbaikan kesehatan masyarakat dapat membuat kemiskinan masyarakat menjadi menurun, itu yang terpenting.

Keterhubungan menjadi kata kunci dalam systems theory yang disebutkan Meadows untuk menganalisis masalah kemiskinan dan meninjau tujuan yang dihasilkannya. Berdasarkan gambaran data yang disajikan BPS, keterhubungan dapat diringkas sebagai:

“...Kemiskinan akan dapat ditekan bila pendidikan masyarakat terjamin dengan baik dan disesuaikan dengan kebutuhan pasar/perusahaan yang menjamur di Indonesia. Kemudian, kapital pun harus memberikan upah yang lebih baik agar masyarakat yang bekerja bisa berkontribusi dalam penghidupan keluarganya lewat pendidikan maupun kesehatan. Dengan adanya kesehatan yang begitu baik, produktifitas untuk bekerja pun dapat pula terwujud dengan baik..."

Konsep keterhubungan sebagaimana dijelaskan memang tepat untuk dilaksanakan dalam tujuan yang kompleks sebagaimana tertera dalam SDGs. Akan tetapi, elemen dan keterhubungan tidaklah merupakan komponen yang penting bila tanpa tujuan. Indikator ketiga dalam systems theory Meadows yakni adanya fungsi atau tujuan merupakan suatu pencapaian yang ada pada sistem. Bila melihat 
keterhubungan dalam masalah kemiskinan, fungsi atau tujuan yang harus tercapai adalah kesejahteraan. Kesejahteraan dalam hal ini memang luas pemaknaannya, akan tetapi paling tidak dengan adanya tujuan pembangunan ialah dapat tercapainya pemenuhan kebutuhan untuk kehidupan seharihari pada masyarakat agar tidak mengalami pengrusakan lingkungan seperti kata Hunter, rentan sakit, maupun jurang ketimpangan sosial ekonomi dan spiritual menurut Scharmer.

\section{PENUTUP}

Setiap alat analisis memiliki kelebihan masing-masing dalam menganalisis masalah dan keterkaitannya pada hal lain yang berhubungan. Hal tersebut seperti: (1) Jurang ketimpangan dapat melihat kerusakan di setiap bidang yang ada di bumi; (2) Iceberg model dapat melihat hingga paradigma yang ada di suatu masalah; dan (3) System theory lebih mampu melihat elemen, keterhubugannya, dan tujuan yang harus dicapai bila ada permasalahan terus-menerus. Akan tetapi secara keseluruhan alat analisis tersebut menggambarkan sebuah tujuan yang harus dicapai bila dihadapkan masalah kemiskinan, yakni terwujudnya suatu kesejahteraan dari hal-hal yang ada melalui perbuatan/aktifitas yang positif di sekitarnya, seperti lingkungan tempat tinggal diperhatikan, pendidikan terjamin, lapangan pekerjaan dibuka luas, maupun hal lain. Dengan begitu, problematika SDGs sendiri diharapkan dapat berkembang untuk dituntaskan permasalahannya.

\section{DAFTAR PUSTAKA}

Avis W.R. 2019. Current Trends in Violent Conflict. Birmingham (UK): University of Birmingham.

[BPS] Badan Pusat Statistik. 2018. Statistik Lingkungan Hidup Indonesia. Jakarta (ID): Badan Pusat Statistik.

[BPS] Badan Pusat Statistik. 2018. Indikator Kesejahteraan Rakyat. Jakarta (ID): Badan Pusat Statistik.

[BPS] Badan Pusat Statistik. 2019. Tingkat Pengangguran Terbuka. Jakarta (ID): Badan Pusat Statistik.

Hunter LM. 2000. The Environmental Implications of Population Dynamics. Santa Monica (CA): A RAND Program of PolicyRelevant Research Communication.

Magniz S. 2016. Pemikiran Karl Marx: Dari Sosialisme Utopis ke Perselisihan
Revisionisme. Jakarta (ID): Gramedia Pustaka Utama.

Marten G. 2001. Human Ecology: Basic Concepts for Sustainable Development. London (UK): Earthscan.

Mawalagedara R dan Oglesby R. 2012. The Climatic effects of deforestation in south and southeast asia. Deforestastion Around the World. Di dalam: Paulo Moutinho, editor. Rijeka (HR): InTech.

Meadows Donella. 2008. Thinking in Systems: A Primer. Di dalam: Diana Wright, editor. London (UK): Earthscan.

Monat J. What is systems thinking? A review of selected literature plus recommedations. American Journal os Systems Science, Vol 4 (1). 11-26.

Pratiwi P. 2008. Kebijakan nasional terhadap pembangunan berwawasan lingkungan. DIMENSIA, Vol 2 (1). 101-112.

Schafer. 2018. The Drivers of Conflict: Where Climate, Gender, And Infrastructure Intersect. New York (US): World Bank.

Scharmer O dan Kaufer K. 2013. Leading from The Emerging Future: From Ego-System to Eco-System Economies. California (US): Berrett-Koehler Publishers.

Sfeir-Younis. 2004. Spirituality and Public Policy for Decent Work: SelfRealization in the New Millennium. Geneva $(\mathrm{CH})$ : World Bank Special Representative to the United Nations and the World Trade Organization.

Uar N, Murti S, dan Hadisusanto S. 2016. Kerusakan lingkungan akibat aktivitas manusia pada ekosistem terumbu karang. Majalah Geografi Indonesia, Vol 30 (1). 88-95.

[UN] United Nations. 2019. Sustainable Development Goals Knowledge Platform [Internet]. [Dikutip tanggal 28 Oktober 2019]. New York (US): United Nations. Dapat diunduh pada: https://sustainabledevelopment.un.org/?menu= $\underline{1300}$

Wahyuni ES dan Rusli S. 2007. Penduduk, organisasi, lingkungan, dan teknologi. Di dalam: Soeryo Adiwibowo, editor. Ekologi Manusia. 2007 Agustus. Bogor (ID): Fakultas Ekologi Manusia Institut Pertanian Bogor.

[WWF] World Wildlife Fund. 2019. The Art of Systems Change: Eight Guiding Principles for A Green and Fair Future. Washington DC (US): World Wildlife Fund. 